\title{
SELECTED INDICATORS OF BONE METABOLISM IN PATIENTS AFTER KIDNEY TRANSPLANT
}

\author{
Sadek Al-Jabry ${ }^{\mathrm{a}}$, Karel Krejčía, Vladko Horčička jra., Pavel Štrebl ${ }^{a}$, \\ Monika Hrabalováb, Petr Bachleda ${ }^{\mathrm{b}}$, Josef Zadražil ${ }^{\mathrm{a}}$ \\ a $\quad 3^{\text {rd }}$ Clinic of Internal Medicine, Teaching Hospital and Faculty of Medicine, Palacky University, \\ Olomouc, Czech Republic \\ ${ }^{b} \quad I^{\text {st }}$ Clinic of Surgery, Teaching Hospital, I. P. Pavlova 22, 77500 Olomouc, Czech Republic
}

Received: September 28, 2003; Accepted (with revisions): November 7, 2003

Key words: Renal osteopathy / Kidney transplant / Hyperparathyroidism / Parathormone / Calcitriol / Bone density

Bone metabolism defects and skeleton diseases, so called renal osteopathy (RO), represent very serious clinical problems in the care of patients with kidney dysfunction. Renal osteopathy is a complicated skeletal disorder with a very complicated pathogenesis and we can encounter its individual forms in kidney transplant patients.

\section{INTRODUCTION}

Kidney transplant is indicated method for chronic kidney failure in some patients. After successful kidney transplant, bone metabolism may improve owing to normalization of serum levels of calcium, phosphorus and the restoration of calcitriol production. However a successful transplantation is no guarantee of complete adjustment to pre-existing RO. In addition in kidney transplant patients bone complications related to long-term immunosuppressive therapy are often manifest.

\section{OBJECTIVE}

The prime objective of the presented prospective study was an evaluation of the development of selected bone metabolism indicators and bone density within a two-year time period following a kidney transplant. A partial objective was assessment of the effectiveness of prophylactic administration of D-vitamin and calcium preparations for the prevention of osteopathy progression following kidney transplant.

\section{POPULATION AND METHODOLOGY}

The patient population consisted of 40 patients who received a cadaverous kidney. There were 22 males and 18 females average age of $51.5 \pm 13.2$ years. After transplantation all patients were treated with a combination of cyclosporin-A, mycophenolate mophetil or azathioprin and after the transplantation, they were prophylactically given AD-vitamin and calcium effervescens in doses of $1,000 \mathrm{mg} \mathrm{Ca}$ effervescent tablets and $800 \mathrm{IU}$ AD-vitamin. During the whole two-year period of monitoring, the serum creatinine concentration in all individuals was lower than $200 \mu \mathrm{mol} / 1$. During the transplantation (up to 2 weeks) and two years after the kidney transplant, the concentration of serum parathormon (PTH), serum level of bone fraction of alkaline phosphatase (ALP), serum phosphorus $(\mathrm{P})$ and calcium $(\mathrm{Ca})$ concentration and $\mathrm{P}$ and $\mathrm{Ca}$ loss in urine/24 hours were examined in all the monitored patients. In the same time period, radiographic pictures of thoracic and lumbar spine and hip joints were taken and by means of Dual-Energy-X-Ray, the bone density (BMD) in the L spine area and femur cervix was determined.

\section{RESULTS}

The results are presented in the form of tables 1-3 and are shown individually for the subgroup of patients with creatinine content lower than $120 \mu \mathrm{mol} / 1$ and for the subgroup of patients with creatinine concentration in the range of $120-200 \mu \mathrm{mol} / 1$.

In individuals with creatinine concentration $<120 \mu \mathrm{mol} / 1$, two years after the kidney transplant, the average PTH concentration was $82.92 \pm 66.01 \mathrm{pg} / \mathrm{ml}$ while in patients with creatinine concentration $>120 \mu \mathrm{mol} / \mathrm{l}$, the average PTH concentration was $140.34 \pm 150.41 \mathrm{pg} / \mathrm{ml}$ (Table 1).

Two years after the transplantation, in 20 individuals with creatinine concentration $<120 \mu \mathrm{mol} / 1$, there was a decrease of BMD in 7 patients (35\%) in the L spine area and in 9 patients (45\%) in the femur cervix area. An increase in BMD occurred in 2 patients ( $10 \%$ ) in the $\mathrm{L}$ spine are and only in one patient in the femur cervix area. A stabilized bone density finding in the $\mathrm{L}$ spine area was detected in 11 patients $(55 \%)$ and in 10 patients in the femur cervix area (Table 2).

In 20 other patients with creatinine concentrations over $120 \mu \mathrm{mol} / 1$, there was a BMD decrease in 9 patients 
(45\%) in the L spine area and in 10 patients ( $50 \%$ ) in the femur cervix area. A BMD increase occurred in 2 patients $(10 \%)$ in the $\mathrm{L}$ spine area and in 3 patients in the femur cervix area. Stabilized BMD was found in 9 individuals $(45 \%)$ in the L spine area and in 7 patients (35\%) in the femur cervix area (Table 3 ).

Table 1. Biochemical findings in patients a 2 years after kidney transplant.

$\left(\mathrm{a}_{\mathrm{n}}=20\right)$

\begin{tabular}{|l|c|c|}
\hline Indicator & $\begin{array}{c}\text { Creatinine } \\
<120 \mu \mathrm{mol} / 1 \\
\mathrm{n}=20\end{array}$ & $\begin{array}{c}\text { Creatinine } \\
120-200 \mu \mathrm{mol} / 1 \\
\mathrm{n}=20\end{array}$ \\
\hline $\begin{array}{l}\text { Parathormon } \\
(\mathrm{pg} / \mathrm{ml})\end{array}$ & $82.99 \pm 66.01$ & $140.34 \pm 150.41$ \\
\hline $\begin{array}{l}\mathrm{ALP} \\
(\mu \mathrm{kat} / \mathrm{l})\end{array}$ & $1.26 \pm 0.53$ & $1.39 \pm 0.50$ \\
\hline $\begin{array}{l}\text { Serum Ca } \\
(\mathrm{mmol} / \mathrm{l})\end{array}$ & $2.46 \pm 0.14$ & $2.40 \pm 0.15$ \\
\hline $\begin{array}{l}\text { Urine Ca } \\
(\mathrm{mmol} / 24 \text { hours })\end{array}$ & $1.56 \pm 1.02$ & $1.47 \pm 1.06$ \\
\hline $\begin{array}{l}\text { Serum P } \\
(\mathrm{mmol} / \mathrm{l})\end{array}$ & $1.13 \pm 0.26$ & $1.18 \pm 0.25$ \\
\hline $\begin{array}{l}\text { Urine P } \\
(\mathrm{mmol} / 24 \text { hours })\end{array}$ & $7.42 \pm 4.57$ & $7.90 \pm 4.48$ \\
\hline
\end{tabular}

Table 2. Development of densitometric findings in individuals a with creatinine $<120 \mu \mathrm{mol} / 1$.

$\left(a_{n}=20\right)$

\begin{tabular}{|l|c|c|c|c|}
\hline Finding & \multicolumn{2}{|c|}{ L-spine } & \multicolumn{2}{c|}{ Femur cervix } \\
\hline Stabilized & 11 & $55 \%$ & 10 & $50 \%$ \\
\hline Improved & 2 & $10 \%$ & 1 & $5 \%$ \\
\hline Aggravated & 7 & $35 \%$ & 9 & $45 \%$ \\
\hline
\end{tabular}

Table 3. Development of densitometric findings in patients a with level of serum creatinine between 120-200 $\mu \mathrm{mol} / 1$.

$\left(\mathrm{a}_{\mathrm{n}}=20\right)$

\begin{tabular}{|c|c|c|c|c|}
\hline Finding & \multicolumn{2}{|c|}{ L-spine } & \multicolumn{2}{c|}{ Femur cervix } \\
\hline Stabilized & 9 & $45 \%$ & 7 & $35 \%$ \\
\hline Improved & 2 & $10 \%$ & 3 & $15 \%$ \\
\hline Aggravated & 9 & $45 \%$ & 10 & $50 \%$ \\
\hline
\end{tabular}


The major aethiopathogenetic factor leading to bone loss during post-transplantation period is long-term immunosuppressive therapy. The most significant drug with negative effect on bone is generally considered corticosteroids. The negative impact of costicosteroids on bone metabolism results from acceleration of bone resorption and inhibition of new bone production ${ }^{13}$. The costicosteroids inhibit posphate transport on the luminous side of the basal side of the membrane of the proximal tubule and suppress calcium resorption from the digestive tract. Their negative effect on bone is generally dependent on the cumulative dosage ${ }^{12}$. According to the literature, the greatest BMD loss occurs in the first year after kidney transplant when the BMD drop represents up to $10 \%$ of the initial value (Fig. 1-3). During the next period, the drop continues at an average of $1.7 \%$ annually ${ }^{12,15-7,22}$. Furthermore, during rejection episodes and their therapy, cytokines begin to loosen. The cytokines support differentiation of osteoclasts and incite apoptosis of the osteoblasts and osteocytes. Another very serious clinical problem, which represents one of the gravest complications of corticosteroid therapy after the kidney transplant, is avascular bone necrosis. This most frequent is an affliction of the femur cervix.

Bone loss caused by the calcineurin inhibitors (cyclosporin-A and tacrolimus) progresses with increased bone turnover, conditional on stimulated IL-1and IL-2 recrement, originated in activated lymphocytes, particularly in later stages after the transplantation ${ }^{18-20}$. Progression of bone disease can theoretically also occur as a result of nephrotoxic effect of cyclosporin, which may aggravate the functional deterioration of the transplanted kidney and lead to activation of parathyroid function. Calcineurin inhibitors may stimulate also so called algic bone syndrome, which is caused by intrabony hyperten- sion and vasoconstriction and is manifest mostly in early post-transplantation stages ${ }^{12}$.

The remaining immunosuppressive substances, azathioprin, mycophenolate mophetil and TOR inhibitors have no known any unfavorable effects ${ }^{21-22}$.

Based on the results, we can draw the following conclusions:

1. PTH concentration in the serum is higher than in patients with the creatine concentration exceeding $120 \mu \mathrm{mol} / 1$.

2. Development of densitometric findings evaluated 2 years after the transplantation is affected by graft function.

3. The densitometric findings in individuals with the creatinine concentration lower than $120 \mu \mathrm{mol} / 1$ are more frequently stabilized and less frequently aggravated.

4. A large number of patients with the decline in bone density in the post-transplantation period indicates the seriousness of the problem and is a challenge for optimal procedures to be found.

At present, administration of calcium and D-vitamin is recommended for all individuals after kidney transplant. For patients with inadequate graft function, this is recommended in a form of active metabolites (1.25 dihydroxy -cholecalciferol). The significance and indication of bisfosfonates in the therapy and prevention of osteopenia in transplant patients needs to be specified in greater detail in further prospective, on-going long-term studies.

\section{ACKNOWLEDGEMENT}

The study was supported by grant IGA MZ CR NK/7741-3. 

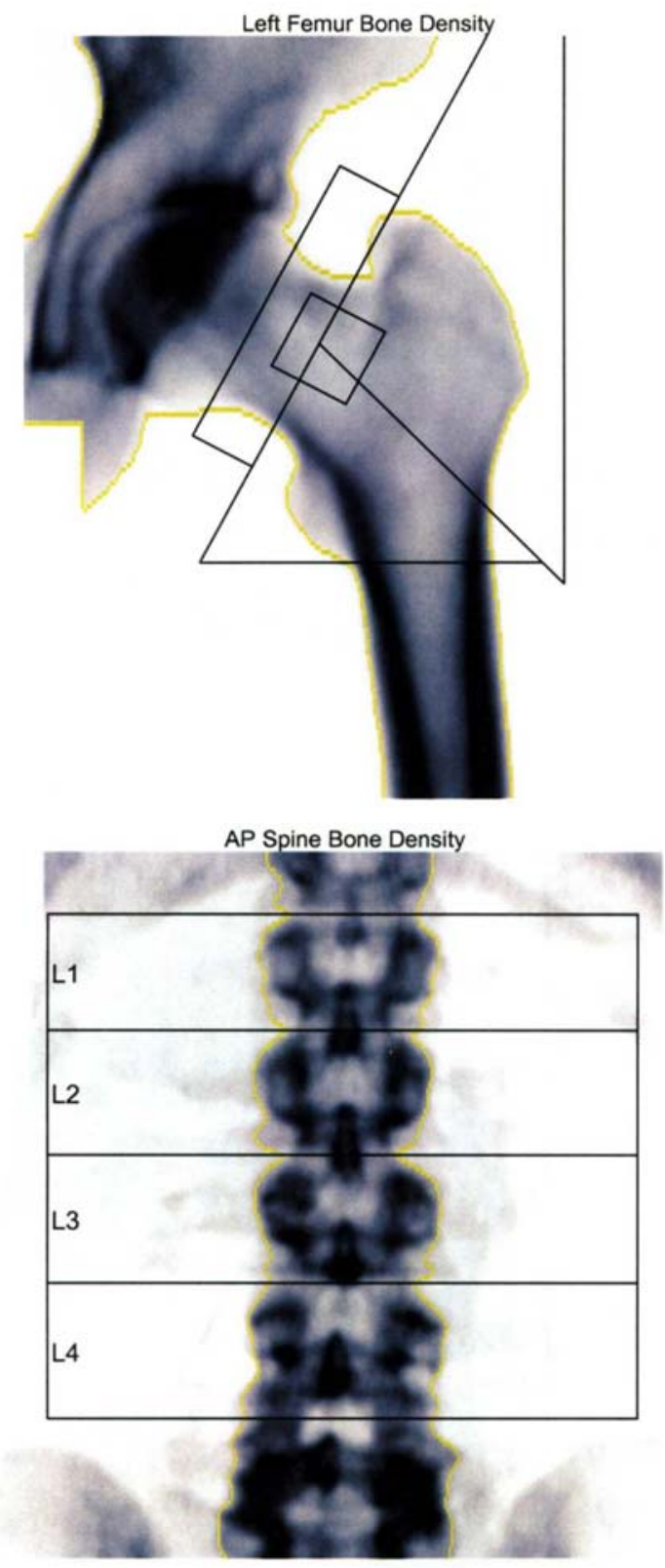

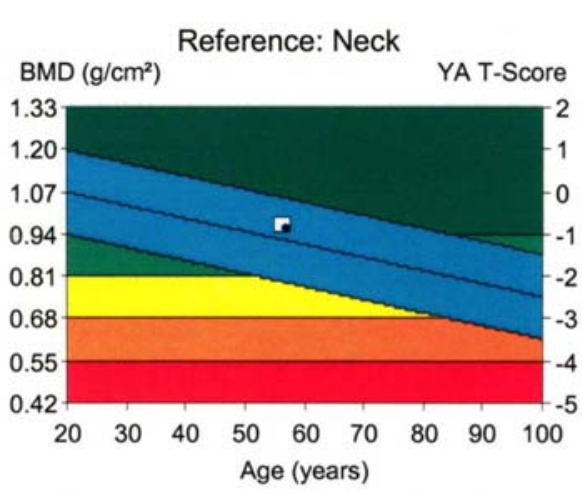

\begin{tabular}{|c|c|c|c|c|c|}
\hline \multirow[b]{2}{*}{ Region } & \multirow{2}{*}{$\begin{array}{c}\mathrm{BMD}^{1} \\
\left(\mathrm{~g} / \mathrm{cm}^{2}\right)\end{array}$} & \multirow{2}{*}{\multicolumn{2}{|c|}{$\begin{array}{l}\text { Young-Adult }{ }^{2} \\
\text { (\%) T-Score }\end{array}$}} & \multicolumn{2}{|c|}{ Age-Matched } \\
\hline & & & & (\%) & Z-Score \\
\hline Neck & 0.966 & 90 & -0.8 & 105 & 0.3 \\
\hline Wards & 0.857 & 89 & -0.8 & 113 & 0.7 \\
\hline Troch & 0.930 & 100 & 0.0 & 110 & 0.7 \\
\hline Shaft & 1.281 & - & - & - & - \\
\hline Total & 1.070 & 98 & -0.2 & 110 & 0.7 \\
\hline
\end{tabular}

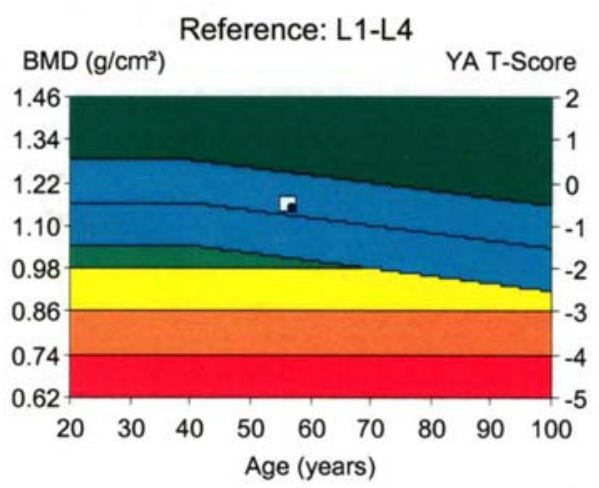

\begin{tabular}{|c|c|c|c|c|c|}
\hline \multirow[b]{2}{*}{ Region } & \multirow{2}{*}{$\begin{array}{l}\text { BMD } \\
\left(g^{1} \mathrm{~cm}^{2}\right)\end{array}$} & \multicolumn{2}{|c|}{ Young-Adult ${ }^{2}$} & \multicolumn{2}{|c|}{ Age-Matched ${ }^{3}$} \\
\hline & & $(\%)$ & T-Score & (\%) & Z-Score \\
\hline L1 & 1.053 & 91 & -0.9 & 98 & -0.1 \\
\hline L2 & 1.177 & 95 & -0.5 & 102 & 0.2 \\
\hline L3 & 1.233 & 99 & -0.1 & 107 & 0.7 \\
\hline L4 & 1.175 & 95 & -0.5 & 102 & 0.2 \\
\hline L1-L3 & 1.158 & 96 & -0.4 & 103 & 0.3 \\
\hline L1-L4 & 1.163 & 95 & -0.5 & 103 & 0.3 \\
\hline L2-L3 & 1.206 & 97 & -0.3 & 105 & 0.5 \\
\hline L2-L4 & 1.194 & 96 & -0.4 & 104 & 0.4 \\
\hline L3-L4 & 1.202 & 97 & -0.3 & 105 & 0.4 \\
\hline
\end{tabular}

Fig. 1. Normal densitometric finding in the L-spine and femur cervix areas.

(Patient: B. V., 1947, 2 months after cadaverous kidney transplant, serum creatinine $100 \mu \mathrm{mol} / \mathrm{l}$ ). 

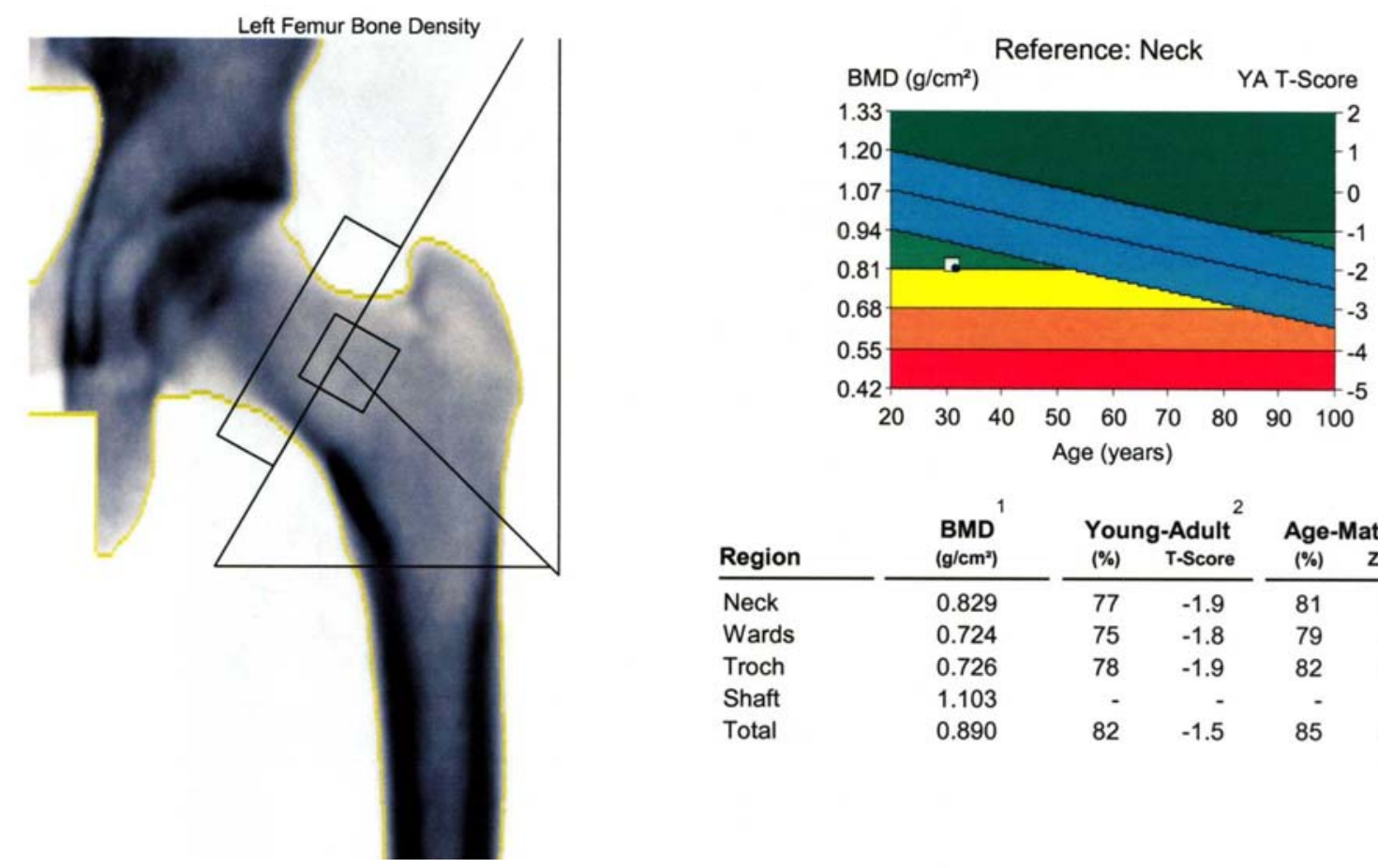

\begin{tabular}{|c|c|c|c|c|c|}
\hline \multirow[b]{2}{*}{ Region } & \multirow{2}{*}{$\underset{\left(\mathrm{g} / \mathrm{cm}^{2}\right)}{\mathrm{BMD}}$} & \multicolumn{2}{|c|}{ Young-Adult ${ }^{2}$} & \multicolumn{2}{|c|}{ Age-Matched } \\
\hline & & (\%) & T-Score & (\%) & Z-Score \\
\hline Neck & 0.829 & 77 & -1.9 & 81 & -1.5 \\
\hline Wards & 0.724 & 75 & -1.8 & 79 & -1.5 \\
\hline Troch & 0.726 & 78 & -1.9 & 82 & -1.5 \\
\hline Shaft & 1.103 & - & - & - & - \\
\hline Total & 0.890 & 82 & -1.5 & 85 & -1.2 \\
\hline
\end{tabular}
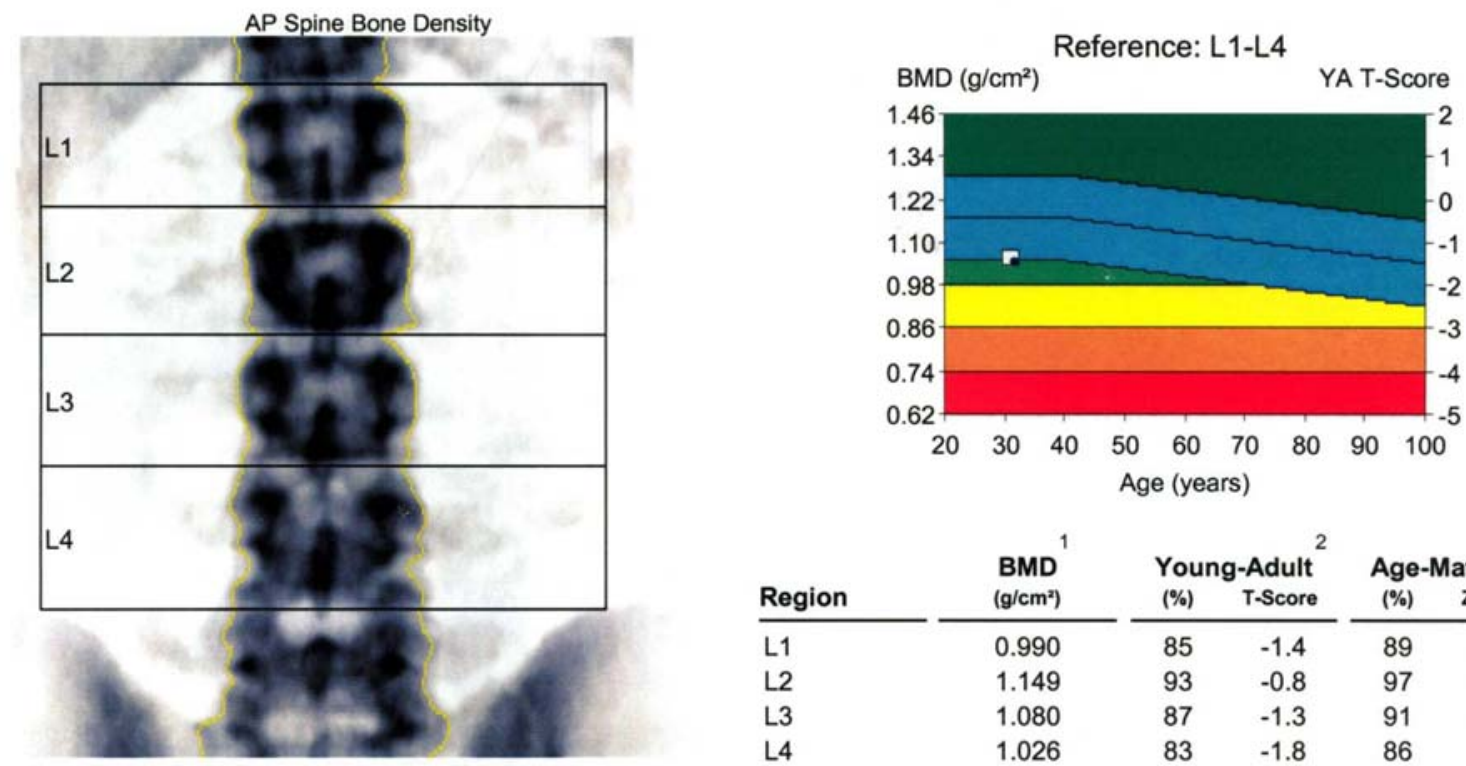

\begin{tabular}{|c|c|c|c|c|c|}
\hline \multirow[b]{2}{*}{ Region } & \multirow{2}{*}{$\underset{\left(\mathrm{g} / \mathrm{cm}^{2}\right)}{{ }^{1}}$} & & \multicolumn{2}{|c|}{ Age-Matched ${ }^{3}$} \\
\hline & & (\%) & T-Score & (\%) & Z-Score \\
\hline L1 & 0.990 & 85 & -1.4 & 89 & -1.0 \\
\hline L2 & 1.149 & 93 & -0.8 & 97 & -0.3 \\
\hline L3 & 1.080 & 87 & -1.3 & 91 & -0.9 \\
\hline L4 & 1.026 & 83 & -1.8 & 86 & -1.4 \\
\hline L1-L3 & 1.074 & 89 & -1.1 & 93 & -0.7 \\
\hline L1-L4 & 1.060 & 87 & -1.3 & 91 & -0.9 \\
\hline L2-L3 & 1.113 & 90 & -1.1 & 94 & -0.6 \\
\hline L2-L4 & 1.080 & 87 & -1.3 & 91 & -0.9 \\
\hline L3-L4 & 1.051 & 85 & -1.6 & 88 & -1.1 \\
\hline
\end{tabular}

Fig. 2. Osteopenia finding in the L-spine (T-score $-1.3 \mathrm{SD}$ ) and femur cervix (T-score - $1.5 \mathrm{SD}$ ) areas. (Patient: S. J., 1972, 6.5 months after cadaverous kidney transplant, serum creatinine $116 \mu \mathrm{mol} / \mathrm{l}$ ). 

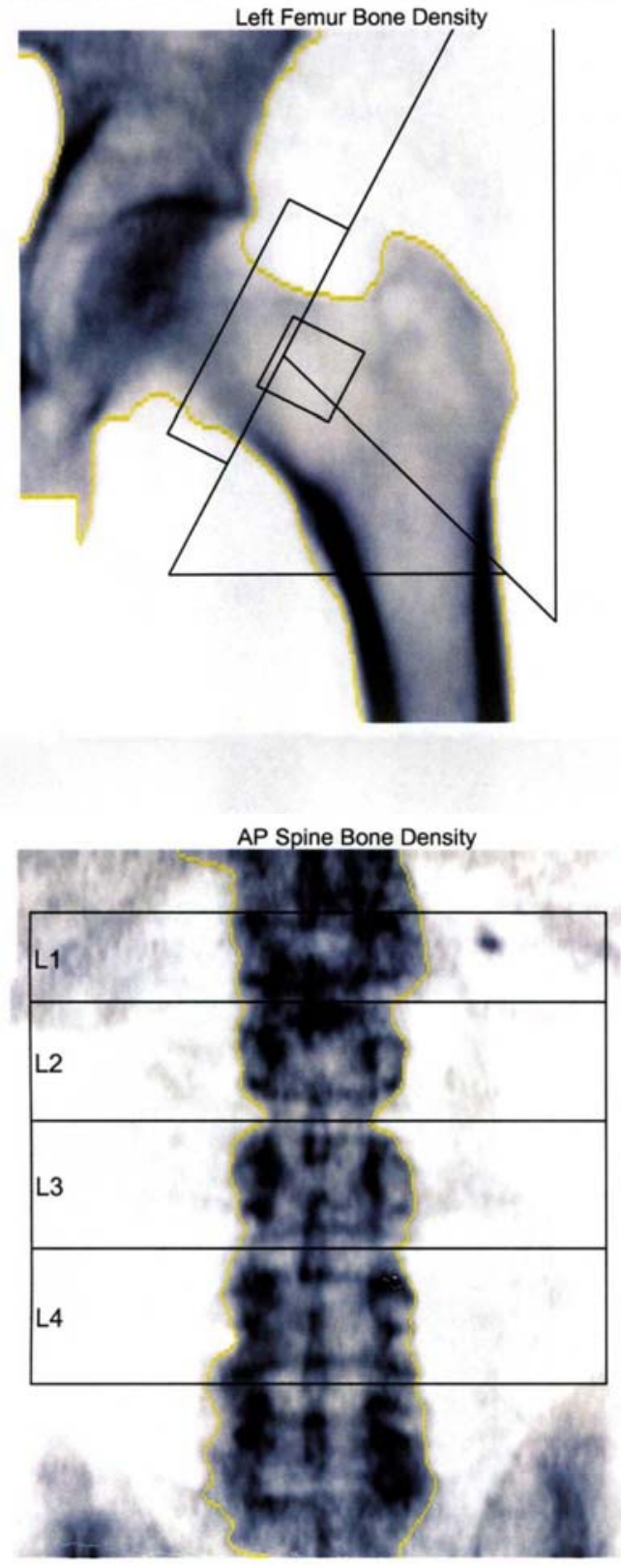

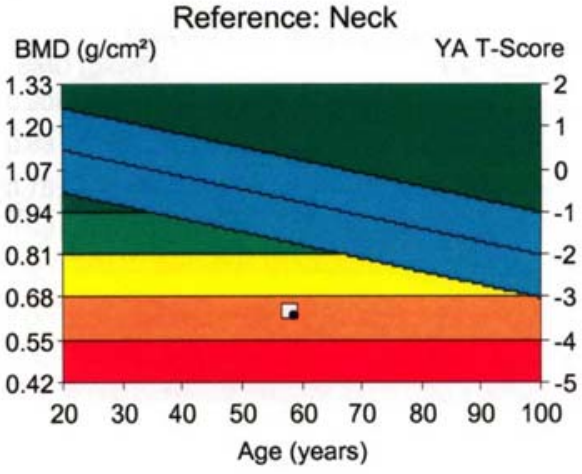

\begin{tabular}{|c|c|c|c|c|c|}
\hline \multirow[b]{2}{*}{ Region } & \multirow{2}{*}{$\underset{\left(\mathrm{g} / \mathrm{cm}^{2}\right)}{\mathrm{BMD}^{1}}$} & & \multicolumn{2}{|c|}{${ }^{3}$} \\
\hline & & & T-Score & (\%) & Z-Score \\
\hline Neck & 0.639 & 60 & -3.3 & 65 & -2.6 \\
\hline Wards & 0.375 & 39 & -4.5 & 46 & -3.3 \\
\hline Troch & 0.640 & 69 & -2.6 & 71 & -2.4 \\
\hline Shaft & 0.920 & - & - & - & - \\
\hline Total & 0.736 & 67 & -2.7 & 71 & -2.3 \\
\hline
\end{tabular}

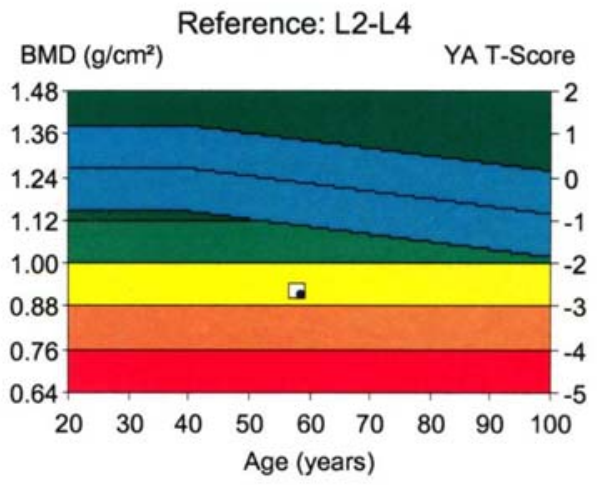

\begin{tabular}{|c|c|c|c|c|c|}
\hline \multirow[b]{2}{*}{ Region } & \multirow{2}{*}{$\underset{\left(g / \mathrm{cm}^{2}\right)}{\mathrm{BMD}^{1}}$} & & \multicolumn{2}{|c|}{ Age-Matched } \\
\hline & & (\%) & T-Score & & Z-Score \\
\hline L1 & 0.966 & 83 & -1.6 & 84 & -1.5 \\
\hline L2 & 0.948 & 76 & -2.4 & 77 & -2.3 \\
\hline L3 & 0.962 & 78 & -2.3 & 78 & -2.2 \\
\hline L4 & 0.883 & 71 & -3.0 & 72 & -2.9 \\
\hline L1-L3 & 0.959 & 79 & -2.1 & 80 & -2.0 \\
\hline L1-L4 & 0.935 & 77 & -2.4 & 78 & -2.3 \\
\hline L2-L3 & 0.956 & 77 & -2.4 & 78 & -2.3 \\
\hline L2-L4 & 0.927 & 75 & -2.6 & 76 & -2.5 \\
\hline L3-L4 & 0.919 & 74 & -2.7 & 75 & -2.6 \\
\hline
\end{tabular}

Fig. 3. Osteoporosis finding in the L-spine (T-score - 2.6 SD) and femur cervix (T-score - 2.7 SD) areas. (Patient: K. L., 1945, 9.5 months after cadaverous kidney transplant, serum creatinine $146 \mu \mathrm{mol} / 1$ ). 


\section{REFERENCES}

1. Sulková Sylvie et al. (2000) Renální osteopatie, Hemodialýza Maxdorf, Praha 21, 404-407.

2. Torres, A, Rodriguez AP, Concepcion MT. (1998) Parathyroid function in long-term renal transplan patients. Nephrol Dial Transplant 13 (suppl 3), 94-97.

3. Torres A, Zarraga S, Rodriguez AP, Gomez Ullate P, Concepcion MT (1998) Optimum PTH levels before renal transplantation to prevent persistent hyperparatgyroidism. J Am Soc Nephrol 9, 572A.

4. Yano S, Sugimoto T, Tuskamoto T. (2000) Association of decreased calcium-sensing receptor expression with proliferation of parathyroid cells in secondary hyperparathyroidism. Kidney Int 58, 1980-1986.

5. UpToDate (2000), Citation: Parathroid and mineral metabolism after renal transplantation. Persistent hyperparathyroidsm and hypercalcemia.

6. Moneir-Fraugere M-C, Geng Z, Maward H. (2001) Improved assessement of bone turnover by the PTH/large C-PTH fragments ratio in ESRD pacients. Kidney Int., 1460-1468.

7. Casez JP. (2002) Changes in bone metabolism mineral density over 18 monthes follwing kidney transplantation: the respective roles of prednison and parathyroid hormon. Nephrol Dial Transplant 17 , 1318-1326.

8. Reinhardt W, Bartelworth H, Jokenhovel F, Shmiddt-Gayk H (1998). Sequential changes of biochemical bone parametrs after kidney transplantation. Nephrol Dial Transplant. 13, 436-442.

9. Moshe L. (2001) Postr-transplant hypophosphatemia. Kidney Int., 2377-2387.

10. Monegal A, Navasa A, Guanabens N. (2001) Bone disease after liver transplantation: along term prospective study of bone mass changes, hormonal status and histomorphometric characteristics. Osteoporosis Int. 12, 484-492.

11. Reinhardt W, Bartelworth H, Jockenhovel F, Schmidt-Gayk H (1998). Sequential changes of biochemical bone parametrs after kidney transplantation. Nephrol Dial Transplant. 13, 436-442.
12. Armando T, Lorenzo V and Salido E. (2002) Calcium Metabolism and Skeletal problems after Transplantation. Am Soscity Nephrol 13, 551-558.

13. Weinstein RS, Jilka RL, Parfitt AM., Manolagas SC (1998). Inhibition of osteoclastogenesis and promotion of apoptosis of osteoblasts and osteoclasts by glucocorticoids, potencial mechanisms of their deleterious effects on bone. J Clin Invest 102, 274-282.

14. Casez JP. (2002) Changes in bone metabolism mineral density over 18 monthes follwing kidney transplantation, the respective roles of prednison and parathyroid hormon. Nephrol Dial Transplant 17, 1318-1326.

15. Weber TJ, Linka A, Quarles LD. (2000) Preventing bone loss after renal transplantation with bisphosphonates, We can ... but should we? Kidney Int 57, 735-737.

16. Bianda T, Linka A, Junga, G. (2000) Prevention of osteoporosis in heart transplant recipeients, A comparison of calcitriol with calcitonin and pamidronate. Calcif Tissue Int 67, 116-121.

17. Pichette V, Bonnardeaux Am, Prudhomme, L. (1996) Long term bone loss in kidney transplant recipients, A cross-sectional and longitudinal study. Am J Kidney Dis 28, 105-114.

18. Sprague SM. (2000). Mechanism of transplantation- associated bone loss. Pediatr Nephrol 14, 650-653.

19. Cayco AV, Wysolmerski J, Simpson, CH (2000). Post-transplant bone disease,evidence for a high bone resorption intake. Transplantation 70, 1722-1728.

20. Thiébaud D, Krieg, Ma., Gillard- Beurger D.(1996) Cyclosporin induces high bone turover and may contribte to bone loss after heart transplantation. Europ J Clin Investig. 26, 549-555.

21. Moneir-Faugers M-C, Mawad H. (2000). High prevalence of low bone turnover and occurrence of osteomalacia after kidney transplantation. J Am Soc Nephrol. 11, 1093-1099.

22. Dissanayker IR, Epstein S (1998). The fate of bone after renal transplantation.Cur open Nephrol Hypertention 7, 389-395.

23. Martins L, Quieros J, Ferreira A.(1991) Rapid loss of vertebral mineral density after renal transplantation. N Engl J Med 325, 2599-2601. 